\title{
The predatory mite Typhlodromalus aripo prefers green-mite induced plant odours from pubescent cassava varieties
}

\author{
Alexis Onzo $\cdot$ Rachid Hanna $\cdot$ Maurice W. Sabelis
}

Received: 17 March 2012/Accepted: 19 June 2012/Published online: 29 June 2012

(C) The Author(s) 2012. This article is published with open access at Springerlink.com

\begin{abstract}
It is well known that plant-inhabiting predators use herbivore-induced plant volatiles to locate herbivores being their prey. Much less known, however, is the phenomenon that genotypes of the same host plant species vary in the attractiveness of these induced chemical signals, whereas they also differ in characteristics that affect the predator's foraging success, such as leaf pubescence. In a series of two-choice experiments (using a Y-tube olfactometer) we determined the preference of Typhlodromalus aripo for pubescent versus glabrous cassava cultivars infested with the cassava green mite Mononychellus tanajoa and also the preference for cultivars within each of the two groups. We found that when offered a choice between pubescent and glabrous cassava cultivars (either apex or leaves), T. aripo was significantly more attracted to pubescent cultivars. For each cultivar, $M$. tanajoa infested leaves and apices were equally attractive to $T$. aripo. There was however some variation in the response of $T$. aripo to $M$. tanajoa-infested plant parts within the group of pubescent cultivars, as well as within the group of glabrous cultivars. Our study confirms not only that $T$. aripo uses herbivore-induced plant volatiles to search for prey in cassava fields, but it also shows that it can discriminate between glabrous and pubescent cultivars and prefers the latter. This knowledge can be useful in selecting cultivars that are attractive and suitable to $T$. aripo, which, in turn, may promote biological control of the cassava green mite.
\end{abstract}

\footnotetext{
A. Onzo · R. Hanna

Biological Control Centre for Africa, International Institute of Tropical Agriculture, 08 B.P. 0932, Cotonou, Benin, West Africa
}

A. Onzo · M. W. Sabelis Institute for Biodiversity and Ecosystem Dynamics, University of Amsterdam, Kruislaan 320, 1098 SM Amsterdam, The Netherlands

A. Onzo

Faculté d'Agronomie, Université de Parakou, B.P. 123, Parakou, Benin

A. Onzo $(\bowtie)$

IITA-Benin, c/o IITA Ltd., 26 Dingwall Road, Croydon CR9 3EE, UK e-mail: onzalex@yahoo.com 
Keywords Herbivore-induced plant volatiles · Y-tube olfactometer · Phytoseiidae · Olfactory preference $\cdot$ Tetranychidae $\cdot$ Africa

\section{Introduction}

It is now widely accepted that plants can promote the effectiveness of the natural enemies of their herbivores (Price et al. 1980; Sabelis et al. 1999, 2007; Cortesero et al. 2000). They protect themselves against phytophagous arthropods in many ways, ranging from chemical (e.g. toxins, digestibility reducers), to morphological (e.g. pubescence, tissue toughness, refuge) defences that either limit herbivore attacks or increase the efficiency of the natural enemies of herbivores (Dicke and Sabelis 1988; Barret 1994; Walter 1996; Sabelis et al. 1999; Norton et al. 2001). Plants can attract the natural enemies of herbivores by emitting specific volatile chemicals when attacked by herbivores. These volatile chemicals, generally referred to as herbivore-induced plant volatiles (HIPV), are among the main information-conveying agents available to predatory arthropods when searching for prey (Dicke et al. 1990a; Turlings et al. 1990; Sabelis et al. 2007; Onzo et al. 2009).

The quantity and quality of HIPV are affected by many factors such as leaf age, herbivore species, time of the day, light intensity, season and water stress, plant species and cultivar (Takabayashi et al. 1994; Turlings et al. 1995). Several studies have shown that plant genotypes or cultivars of a given plant species produce different blends of HIPV (Turlings et al. 1995; Krips et al. 2001; Scutareanu et al. 2001, 2003). Loughrin et al. (1995) reported that the amount and the composition of emitted volatiles were qualitatively different between commercial and naturalized cotton infested by the beet armyworm, Spodoptera exigua (Hübner). Takabayashi et al. (1991) reported that blends emitted by apple leaves infested with spider mites from either of two different species Tetranychus urticae Koch and Panonychus ulmi (Koch) differed mainly in quantitative composition for some compounds. In contrast, they observed that the blends emitted by leaves of two apple cultivars infested by the same spider mite species - T. urticae-differed significantly both quantitatively and qualitatively (see also Shiojiri et al. 2010 for a similar case).

Sabelis and van de Baan (1983) and Dicke et al. (1990b) observed that the response of Phytoseiulus persimilis Athias-Henriot to the volatiles emitted by two bean cultivars (Phaseolus vulgaris L.) infested by the two-spotted spider mite T. urticae showed a significant difference in their attractiveness to the predatory mite $P$. persimilis. More recent studies on pear cultivars (Scutareanu et al. 2001, 2003), on gerbera cultivars (Krips et al. 2001) and on maize cultivars (Gouinguené et al. 2001; Tamiru et al. 2011), indicated that different cultivars of the same plant species produce different volatile blends when infested by the same herbivore species. Volatile blends can also differ depending on herbivore genotype even when attacking the same cultivar of plant (Kant et al. 2008).

Field observations in Africa showed that the frequency and abundance of the predatory mite, Typhlodromalus aripo De Leon, differed among cassava cultivars infested by the cassava green mite (CGM) Mononychellus tanajoa (Bondar). This predatory mite inhabits the apex (growing point) of cassava plant branches during day-time, but during night-time it commutes between apex and leaves to forage for CGMs, its prey (Onzo et al. 2003). Cassava apex traits such as size, compactness, and pubescence-particularly the lattermatter to the abundance of $T$. aripo, this predator is more frequently found and more abundant on cassava cultivars with pubescent apices compared with cultivars with glabrous apices (Hanna et al. 2000; Zundel et al. 2009). As one of the possible explanations for the 
differential abundance of $T$. aripo on the various cultivars, we hypothesize that pubescent cultivars produce HIPV that is more attractive to the predatory mite $T$. aripo than glabrous cultivars. In this study, we use olfactometry to test whether adult females of $T$. aripo prefer odours of CGM-infested pubescent cultivars over CGM-infested glabrous cultivars.

\section{Materials and Methods}

We used a Y-tube olfactometer (Sabelis and van de Baan 1983; Takabayashi and Dicke 1992) to determine the extent to which $T$. aripo predators are attracted to pubescent and glabrous cassava genotypes. The Y-tube olfactometer consisted of a Y-shaped glass tube with a Y-shaped iron wire positioned in the middle, and parallel to the tube walls to provide a 'railroad' to the mites. The base of the Y-tube was connected to an air pump that produced a unidirectional airflow from the arms to the base of the tube. The arms were connected via a plastic tube to two identical plastic boxes each of which contained a test odour sources (e.g. Aratchige et al. 2004).

Preparation of plant parts for use in the Y-tube olfactometer two-choice tests followed the same protocol for all three experiments. Cassava apices and leaves of all seven cultivars used in this study were collected from mite-free cassava plants grown in large pots under semi-field conditions in a screenhouse (Onzo et al. 2005) of the International Institute of Tropical Agriculture in Cotonou, Benin. The potted cassava plants were 4-5 weeks old by the time their leaves and apices were picked for use in the experiments.

Field-collected individuals of M. tanajoa were maintained indoors or in a screenhouse on potted cassava plants. Specimens of $T$. aripo used in the experiments were also collected from cassava fields at the IITA-Station or close to IITA campus, then put in paper bags and kept in a refrigerator at c.a. $12{ }^{\circ} \mathrm{C}$ in a laboratory before their use in the experiments.

Leaves and apices used as odor sources were detached from cassava plants in the morning and then each with their petiole placed immediately in a water-filled glass vial (0.8 $\mathrm{cm}$ in diameter and $4 \mathrm{~cm}$ deep), or each with their stem end $(10 \mathrm{~cm}$ below the apex) in a larger water-filled plastic vial $(2.7 \mathrm{~cm}$ in diameter and $6.5 \mathrm{~cm}$ deep). The vials were sealed with parafilm to keep the plant tissue fresh during the experiment (Gnanvossou et al. 2003). Leaves were collected from the top of the canopy (i.e. leaf 3-4), because green mites prefer young cassava leaves. In the afternoon of the same day, 25 adult females $M$. tanajoa were used to infest each leaf, whereas 5 adult females $M$. tanajoa were used to infest each apex (Gnanvossou et al. 2001; 2003). The M. tanajoa infested plant tissues were then incubated in plastic cages (70 cm long, $40 \mathrm{~cm}$ wide and $40 \mathrm{~cm}$ high), for 3 days under continuous light provided by two fluorescent light sources placed above the cages. Cassava plant parts from different cultivars were incubated in separate cages (but in the same room). For each set of olfactometer experiments, odor source consisted of four $M$. tanajoa-infested leaves or $16 \mathrm{M}$. tanajoa-infested apices to obtain matching amounts of plant biomass (Gnanvossou et al. 2003).

Adult females of $T$. aripo were kept individually in a plastic vial $(10 \mathrm{~mm}$ diam. and $40 \mathrm{~mm}$ long) without food for $2 \mathrm{~h}$ prior to the olfactometer bioassays (see Gnanvossou et al. 2001). To investigate the olfactory response of $T$. aripo to the different cassava cultivars, three separate series of Y-tube experiments were conducted. In the first series of experiments we compared the response of $T$. aripo to volatiles from pubescent and glabrous cassava cultivars infested by $M$. tanajoa to determine whether $T$. aripo has a preference. The pubescent genotypes were represented by the cultivars Agric, TMS 92/0326, 
Oko-Iyawo, whereas the glabrous cultivars were represented by cultivars Gbeze, Odongbo, TMS 30572 and Amala. All these cultivars, except Gbeze, were used in the field studies described by Hanna et al. (2000). Each cultivar in a group (i.e. pubescent or glabrous) was tested against each cultivar in the other group.

In a second series of Y-tube experiments with the same cultivars as in the first, we tested whether the different pubescent (or glabrous) cultivars were equally attractive to T. aripo. All combinations of cultivars within each of the two categories (pubescent/glabrous) were compared. Thus, the three pubescent cultivars were compared in two-choice tests as follows: (1) apex of Oko-Iyawo versus apex of TMS 92/0326; (2) apex of Oko-Iyawo versus apex of Agric; and (3) apex of Agric versus apex of TMS 92/0326. Similarly the four glabrous cultivars were compared in two-choice tests as follows: (1) Apex of Gbeze versus apex of TMS 30572; (2) apex of Gbeze versus apex of Odongbo; (3) apex of Gbeze versus apex of Amala; (4) apex of TMS 30572 versus apex of Odongbo; (5) apex of TMS 30572 versus apex of Amala; and (6) apex of Amala versus apex of Odongbo.

In a third series of Y-tube experiments, we compared the attraction of $T$. aripo to leaves and apices of pubescent and glabrous cassava cultivars. The objective was to determine whether attraction of $T$. aripo is to the apex alone or to cassava leaves alone or to both. In this experiment, apices and leaves of the glabrous cultivar Gbeze or those of the pubescent cultivar Agric were used in two-choice tests in the Y-tube olfactometer as follows: (1) apex of Gbeze versus apex of Agric; (2) leaf of Gbeze versus leaf of Agric; (3) leaf of Gbeze versus apex of Agric; (4) apex of Gbeze versus leaf of Agric; and (5) apex of Agric versus leaf of Agric. Because the cultivar Gbeze was relatively less colonized by $T$. aripo, we decided not to test the combination of apex of Gbeze versus leaf of Gbeze.

Each of the two arms of the Y-tube olfactometer had an air stream coming from one of the two boxes, each with a different odor source. Each individual predator was placed at the base of the iron wire positioned in the middle of the Y-shaped glass tube and parallel to the tube walls (Sabelis and van de Baan 1983). The predator was observed until it reached the end of one of the two arms, or for a maximum of $5 \mathrm{~min}$, after which it was removed. After testing a series of five consecutive females, the odor sources were interchanged to correct for any unforeseen asymmetry in the experimental set-up (Sabelis and van de Baan 1983). The number of females reaching each odor source, as well as those that did not make a choice was recorded. In each replicate experiment $20 \mathrm{~T}$. aripo females were tested sequentially in two-choice tests in the Y-tube olfactometer and each experiment was replicated three times, taking place on consecutive days. New odor sources were used each day.

\section{Statistical analysis}

To analyze the olfactometer results we used a replicated G-test against the null hypothesis that predators reach the end of the two arms with equal probability (1:1) (Sokal and Rohlf 1981). This test yields three G-statistics: $G_{P}, G_{H}$ and $G_{T}$. If $G_{T}$ is significant, then this may due to heterogeneity among replicates. This is why it is important to test for heterogeneity. If $G_{H}$ is not significant, then the conclusions can be based on a G-test on pooled data $\left(G_{P}\right)$. If the $\mathrm{G}_{\mathrm{H}^{-}}$-test is significant, however, the significance of $\mathrm{G}_{\mathrm{T}}$ may be due to heterogeneity among replicates. In that case the variation among replicates has to be scrutinized before drawing conclusions (see Aratchige et al. 2004 for an example). Females that failed to walk to the far end of one of the arms were not included in the data subject to the statistical analysis. To facilitate interpretation of the data presented in the Figures, critical $\mathrm{P}$ values from binomial tests against a 1:1 hypothesis are provided for the pooled data for each 
treatment (Zar 1984). Also here, females that failed to walk to the far end of one of the arms were not included in the statistical analysis.

\section{Results}

Attraction of Typhlodromalus aripo to volatiles emitted by apices or leaves of pubescent versus glabrous Mononychellus tanajoa-infested cassava cultivars

In all comparisons, $T$. aripo was attracted mainly to apices of the pubescent cultivars (Table 1; Fig. 1). The proportions of predators that chose apices of the pubescent cultivars were statistically larger than those that chose apices of the glabrous cultivars, with two exceptions: the proportions of $T$. aripo females that were attracted to the pubescent cultivar Oko-Iyawo compared with the glabrous cultivar Gbeze and those attracted to the pubescent cultivar Agric compared with the glabrous cultivar Odongbo were, in both sets of choices, numerically larger but not significantly different from a 1:1 ratio (Fig. 1). The replicated G test revealed that heterogeneity among replicate experiments (each with 20 predators) was not significant. Hence, it is justified to base the conclusions on a G-test on pooled data and this showed a significant deviation from a 1:1 ratio, confirming that $T$. aripo predators prefer the apices of pubescent cultivars over those from glabrous cultivars.

Similar to the tests with cassava apices, $T$. aripo showed a significant preference for infested leaves from the pubescent cultivar Agric to infested leaves from the glabrous cultivar Gbeze (Table 1; Fig. 4). Since heterogeneity among replicate experiments was not significant, the G-test on pooled results was done and this showed a significant deviation from a 1:1 ratio confirming that the $T$. aripo predators prefer odour of leaves from the pubescent cultivar over odour from leaves a glabrous cultivar (Table 2).

Attraction of Typhlodromalus aripo to volatiles emitted by apices of pubescent versus pubescent, or glabrous versus glabrous Mononychellus tanajoa-infested cassava cultivars

Among pubescent cultivars, T. aripo did not display significant preferences in the comparisons between the cultivars Agric and Oko-Iyawo or between the cultivars Agric and TMS 92/0326. When given a choice between Oko-Iyawo and TMS 92/0326, however, T. aripo significantly preferred the former (Table 1; Fig. 2). Since there was no significant

Table 1 Results of olfactometer tests for the responses of Typhlodromalus aripo to apices of pubescent (+) and glabrous (-) cassava cultivars

\begin{tabular}{|c|c|c|c|c|c|}
\hline Odour sources & No. replicates & $\mathrm{n}(+)$ & $\mathrm{n}(-)$ & $\mathrm{n}(0)$ & $\mathrm{N}$ \\
\hline A. Pubescent apices versus glabrous apices & 36 & 480 & 238 & 2 & 718 \\
\hline B. Pubescent leaves versus glabrous leaves & 3 & 39 & 19 & 2 & 58 \\
\hline C. Pubescent apices versus pubescent apices & 9 & 81 & 99 & 0 & 180 \\
\hline D. Glabrous apices versus glabrous apices & 18 & 166 & 194 & 0 & 360 \\
\hline E. Pubescent apices versus pubescent leaves & 3 & 26 & 34 & 0 & 60 \\
\hline F. Pubescent apices versus glabrous leaves & 3 & 42 & 17 & 1 & 59 \\
\hline G. Pubescent leaves versus glabrous apices & 3 & 39 & 19 & 2 & 58 \\
\hline
\end{tabular}

Number of female predators tested in each replicate experiment is equal to 20 


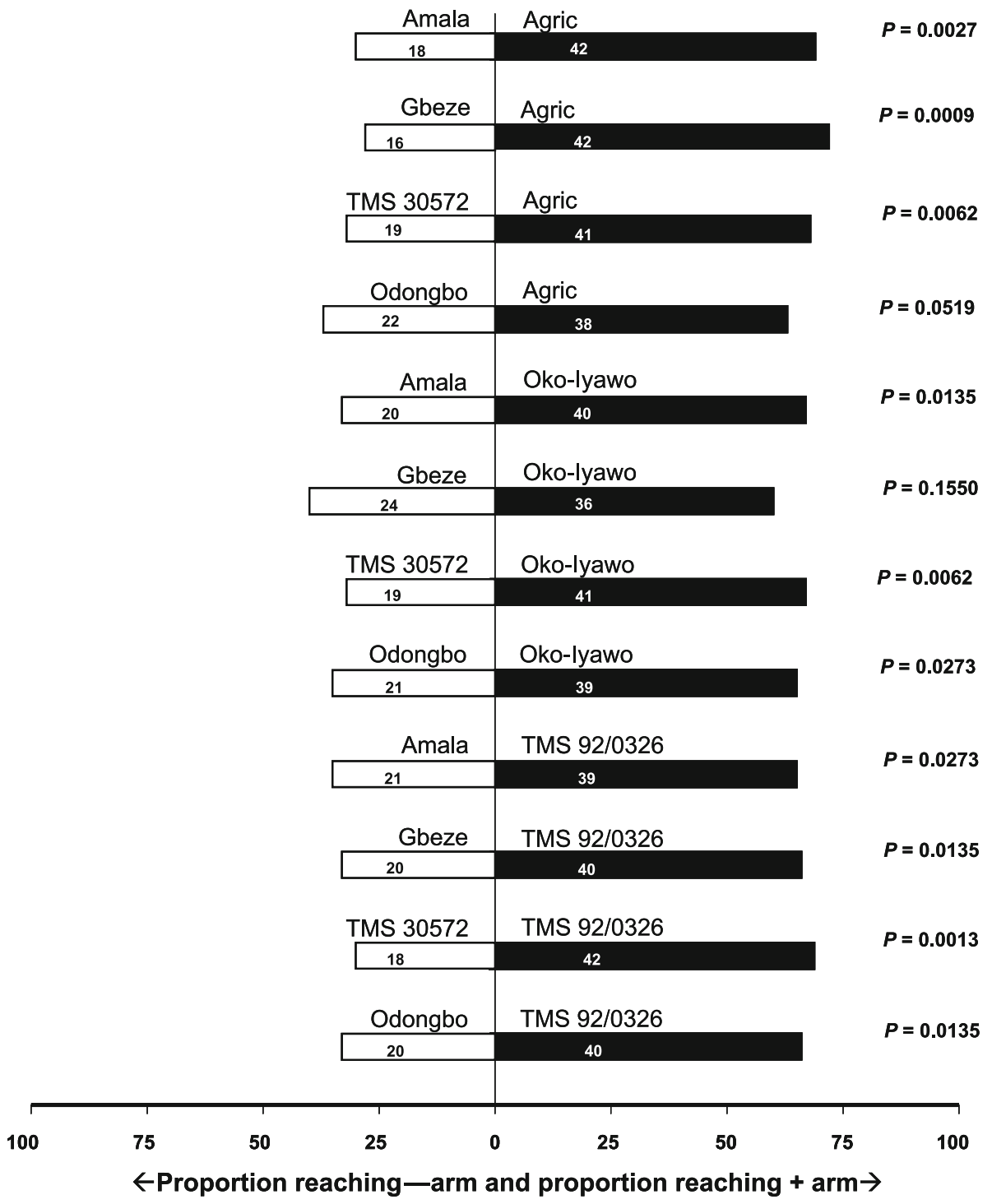

Fig. 1 Response of Typhlodromalus aripo when offered a choice between volatiles from Mononychellus tanajoa-infested apices of pubescent versus glabrous cassava cultivars, in a Y-tube olfactometer. Numbers in the bars represent the total number of predators that chose either olfactometer arm. To the right of each horizontal bar critical $P$ values are given from a binomial test against a 1:1 null hypothesis applied to the pooled data of three replicate experiments [Open bars $=\%$ attracted to glabrous apices $(-\operatorname{arm})$; filled bars $=\%$ attracted to pubescent apices $(+\operatorname{arm})]$

heterogeneity among replicate experiments, a G-test on pooled results was carried out and this did not show a significant deviation from a 1:1 ratio $(P>0.05)$, suggesting that the tested predators had no preference (Table 2).

Similarly among glabrous cultivars (Table 1; Fig. 3), T. aripo did not show a preference in two-cultivar comparisons, except for Odongbo when Amala was the alternative and for 


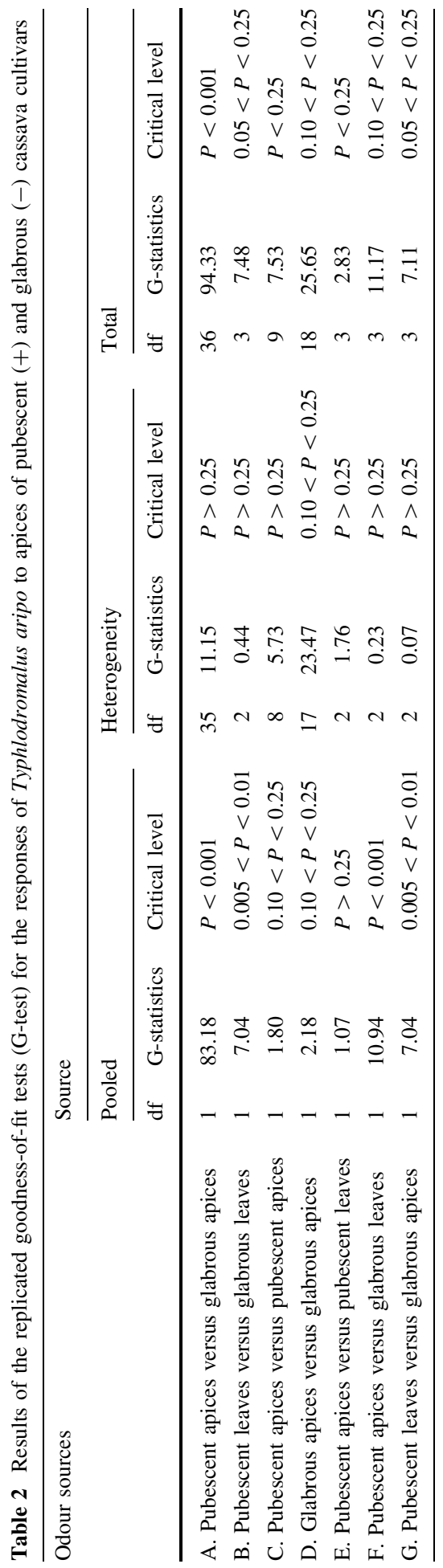




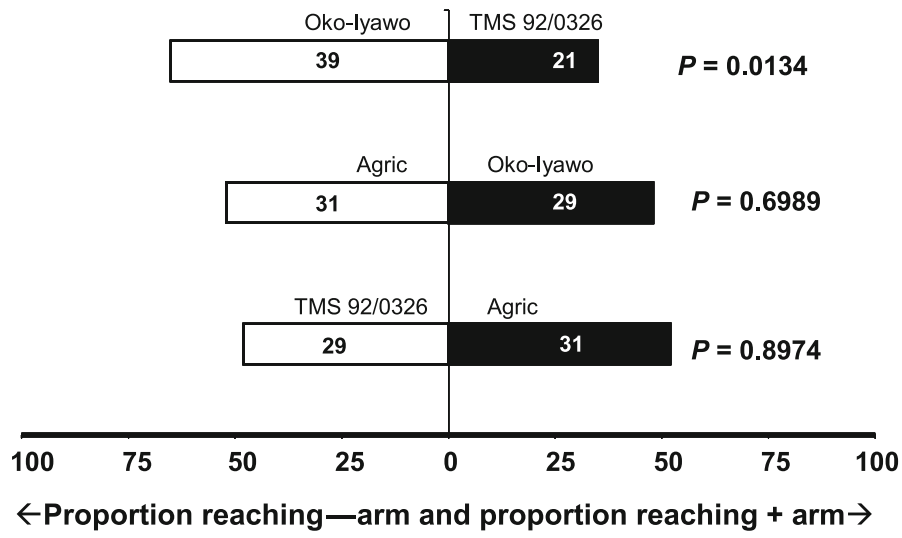

Fig. 2 Response of Typhlodromalus aripo when offered choice between volatiles from Mononychellus tanajoa-infested apices from two pubescent cassava cultivars, in a Y-tube olfactometer. Numbers in the bars represent the total number of predators that chose either olfactometer arm. To the right of each horizontal bar critical $P$ values are given as obtained by a binomial test against a 1:1 null hypothesis [Open bars $=\%$ attracted to pubescent apices $(-\operatorname{arm}) ;$ filled bars $=\%$ attracted to pubescent apices $(+\operatorname{arm})]$

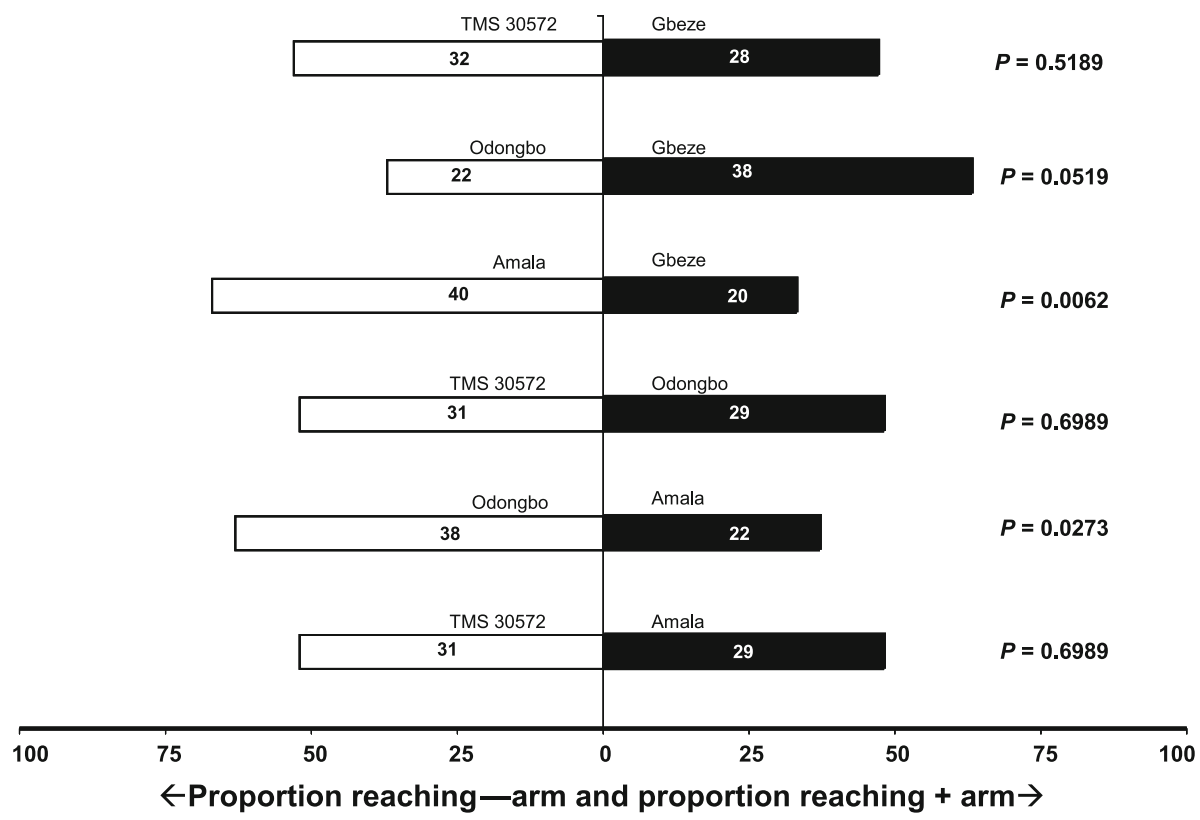

Fig. 3 Response of Typhlodromalus aripo when offered a choice between volatiles from Mononychellus tanajoa-infested apices from two glabrous cassava cultivars, in a Y-tube olfactometer. Numbers in the bars represent the total number of predators that chose either olfactometer arm. To the right of each horizontal bar critical $P$ values are given from a binomial test against a 1:1 null hypothesis applied to the pooled data of three replicate experiments [Open bars $=\%$ attracted to glabrous apices $(-\operatorname{arm}) ;$ filled bars $=\%$ attracted to glabrous apices $(+\operatorname{arm})]$

Amala when Gbeze was the alternative. The non-preference of $T$. aripo among the glabrous cassava cultivars was also confirmed by the pooled results of the replicated goodness of fit tests $(P>0.05$; Table 2$)$. 
Attraction of Typhlodromalus aripo to apex versus leaf of Mononychellus tanajoainfested cassava plants

The predator showed no significant preference when offered infested leaves versus infested apices of the pubescent cultivar Agric (Table 1; Fig. 4). When offered the choice between infested leaves of the glabrous cultivar Gbeze and those of the pubescent cultivar Agric apices, or between Gbeze apices and Agric leaves, T. aripo were significantly more attracted to Agric (whether apex or leaf) (Table 1). These results were also confirmed by the replicated G-tests (Table 2). Since there was no significant heterogeneity among replicate experiments, we proceeded to do a G-test on pooled data and these showed that the predators had a significant preference for odour from infested parts of pubescent cultivars (Table 2).

\section{Discussion}

Our study shows that-in 10 out of 12 two-choice comparisons between pubescent and glabrous cassava cultivars (Fig. 1) - T. aripo preferred pubescent cultivars and that the predator uses HIPV to locate its preferred host plant. This general preference of $T$. aripo for pubescent rather than glabrous cassava cultivars provides at least a partial explanation

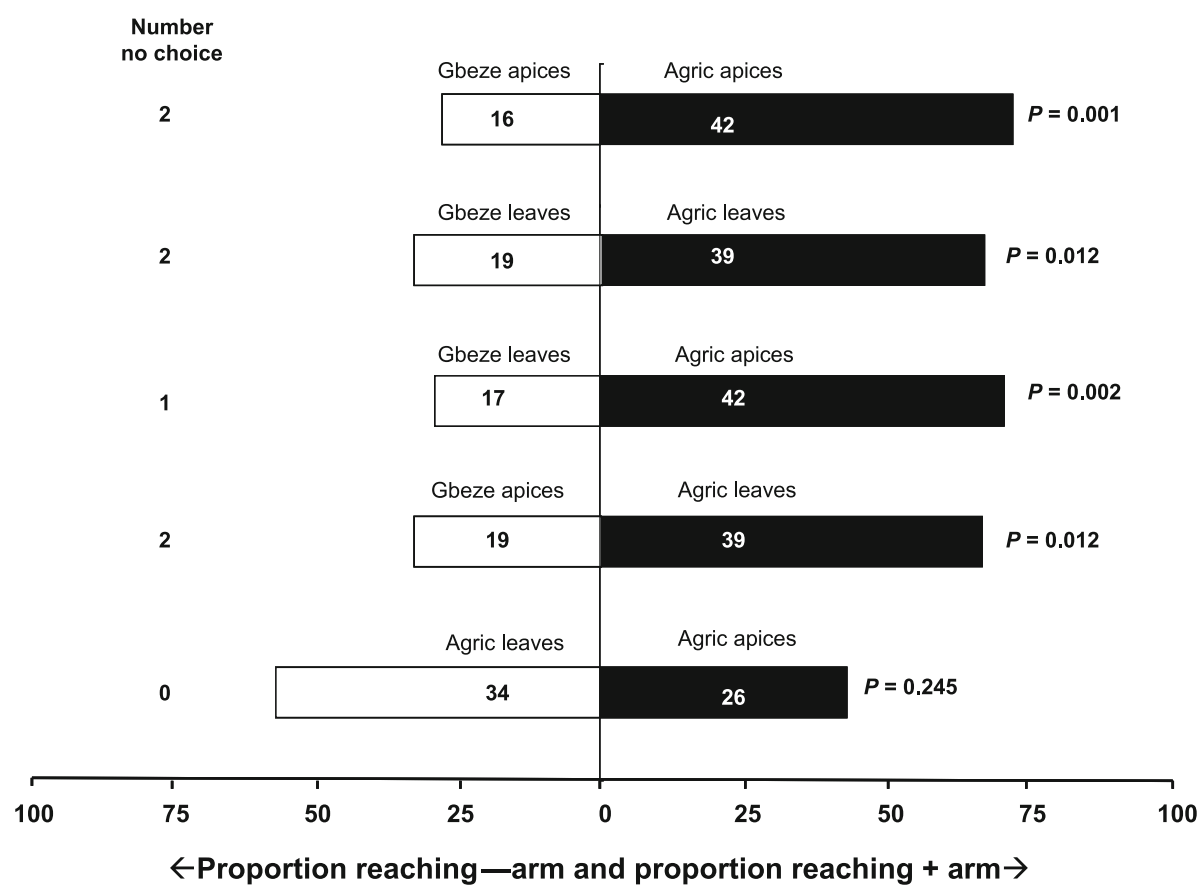

Fig. 4 Response of Typhlodromalus aripo when offered a choice between volatiles from Mononychellus tanajoa-infested apices or leaves of pubescent or glabrous cassava cultivars, in a Y-tube olfactometer. Numbers in the bars represent the total number of predators that chose either olfactometer arm. To the right of each horizontal bar critical $P$ values are given from a binomial test against a 1:1 null hypothesis applied to the pooled data of three replicate experiments [Open bars $=\%$ attracted to glabrous apices or leaves $(-\operatorname{arm}) ;$ filled bars $=\%$ attracted to pubescent apices or leaves $(+\operatorname{arm})]$ 
for the greater abundance of $T$. aripo in the field on pubescent rather than glabrous cultivars (Hanna et al. 2000). Colonization of pubescent cassava cultivars by T. aripo is not, therefore, by chance. Pubescence may increase the relative humidity inside the apex, thereby improving the survival conditions for its residents, especially during the dry season (R. Hanna, personal communication). Whereas it is known from previous studies that residing in the apex provides to $T$. aripo protection against UV-induced mortality (Onzo et al. 2010); it is not yet demonstrated, however, that pubescence reinforces this protection. A novel finding emerging from this study is that the predator uses the volatiles emitted from leaves as well as those from apices. This response may enhance the predator's ability to find its preferred host plant since it is expected that the quantity of volatile blends emitted by leaves is far greater than those by apices alone, because the leaf biomass of a cassava plant is larger than that of its apices.

The differential response of $T$. aripo to pubescent and glabrous cassava cultivars suggests a difference in the composition and/or in the amount of the volatile cues emitted by each of the cassava cultivars, as observed by Hoballah et al. (2002) and Tamiru et al. (2011) for plant varieties with completely different system of host-plant species (maize), phytophagous insect (caterpillar) and natural enemy (parasitoid insect). Pubescent cultivars appeared to produce volatile blends that are more attractive to the predatory mite $T$. aripo than blends produced by glabrous cassava cultivars. Our study also showed some differences in within-group comparisons, notably the clear preference for Oko-Iyawo when tested against TMS 92/0326 in comparisons including only pubescent cultivars, and the clear preference for Odongbo over Amala and Amala over Gbeze in comparisons including only glabrous cultivars. On the basis of findings from comparisons within the glabrous group it was expected that $T$. aripo would have clear preference for Odongbo when tested against Gbeze, since Odongbo was more attractive than Amala, and Amala was more attractive than Gbeze. The results were more close to the opposite, however: there was a numerically higher attraction (and a nearly significant response; $P=0.0519$ ) to Gbeze compared with Odongbo. This may be due to differences in the relative composition or in the amount of volatiles produced by these three glabrous cultivars. Further studies are needed to compare the chemical composition of HIPV emitted by different cassava cultivars under attack by $M$. tanajoa to determine which compounds or which blend of compounds (see van Wijk et al. 2011) are responsible for the attraction of T. aripo. Variation in quantity and quality of odor may well explain within- cultivar group variability in $T$. aripo attraction to pubescent and glabrous cassava cultivars.

Implications for the cassava production system in Africa

Morphological plant characteristics may play an important role in the biological control of agricultural crop pests (Skirvin and Fenlon 2001). They may not only affect herbivores but also their natural enemies (Sabelis and Bakker 1992; Barret 1994; Dicke 1995). Our findings suggest that cassava plant breeders should not only consider the effect of pubescence on the second trophic level but also that on the third trophic level. Thus, by using knowledge of plant-natural enemy interactions instead of aiming only at developing pest/disease-resistant cultivars, plant breeders may produce cultivars with a higher yield under realistic field conditions. In doing so, they may contribute to enhancing predator efficiency by breeding plants emitting a more effective blend of HIPV in that it attracts more natural enemies or helps arresting them on the plants. In selecting a cultivar, plant breeders should, therefore, aim at improving conditions that increase predator-searching behavior thereby increasing the effectiveness of plant pest control (Dicke et al. 1990b). 
Plant volatiles, as well as plant morphological characteristics, may play an essential role in plant-herbivore-predator interactions and are therefore also promising targets for improved crop protection (Kant et al. 2009).

Acknowledgments The authors thank B. Bovis and R. Houndafoché for their technical assistance; and D. Gnanvossou for his valuable comments and suggestions. This research was supported with funds provided to the International Institute of Tropical Agriculture (IITA) by the International Fund for Agricultural Development (IFAD), and with funds provided to the University of Amsterdam and IITA by the Netherlands Foundation for the Advancement of Tropical Research (WOTRO) in the form of a postdoctoral fellowship to A. Onzo.

Open Access This article is distributed under the terms of the Creative Commons Attribution License which permits any use, distribution, and reproduction in any medium, provided the original author(s) and the source are credited.

\section{References}

Aratchige NS, Lesna I, Sabelis MW (2004) Below-ground plant parts emit herbivore-induced volatiles: olfactory responses of a predatory mite to tulip bulbs infested by rust mites. Exp Appl Acarol 33:21-30

Barret D (1994) Influence de l'architecture du phylloplan dans l'organisation des peuplements de phytoséiides (Acari) et dans leurs associations avec les plantes. Thèse de Doctorat. Ecole Nationale Supérieure Agronomique de Montpellier, France, p 174

Cortesero AM, Stapel JO, Lewis WJ (2000) Understanding and manipulating plant attributes to enhance biological control. Biol Control 17:35-49

Dicke M (1995) Crop plants influence the performance of biological agents: implications for integration of host plant resistance and biological control. In: Integrating biological control and hostplant resistance. Proceedings of CTA/IAR/IIBC seminar, Addis Ababa, Ethiopia, 9-14 Oct 1995

Dicke M, Sabelis MW (1988) How plants obtain predatory mites as bodyguards. Neth J Zool 38:148-165

Dicke M, van Beek TA, Posthumus MA, Ben Dom N, van Bokhoven H, De Groot A (1990a) Isolation and identification of volatile kairomone that affects acarine predator-prey interactions. Involvement of host plant in its production. J Chem Ecol 16:381-396

Dicke M, Sabelis MW, Takabayashi J, Bruin J, Posthumus MA (1990b) Plant strategies of manipulating predator-prey interactions through allelochemicals: prospects for application in pest control. J Chem Ecol 16:3091-3118

Gnanvossou D, Hanna R, Dicke M, Yaninek JS (2001) Attraction of the predatory mites Typhlodromalus manihoti and Typhlodromalus aripo to cassava plants infested by cassava green mite. Entomol Exp Appl 101:291-298

Gnanvossou D, Hanna R, Dicke M (2003) Infochemical-mediated niche use by the predatory mites Typhlodromalus manihoti and T. aripo (Acari: Phytoseiidae). J Insect Behav 16:523-535

Gouinguené S, Degen T, Turlings TCJ (2001) Variability in herbivore-induced odour emissions among maize cultivars and their wild ancestors (teosinte). Chemoecology 11:9-16

Hanna R, Ojo D, Yaninek JS, Toko M, Gnanvossou D, Onzo A (2000) Effects of cassava cultivar on abundance of exotic phytoseiid mites in Africa. In: Page 10 in abstract of the XXI international congress of entomology, Iguassu Falls, Brazil, 20-26 August 2000

Hoballah MEF, Tamo C, Turlings TCJ (2002) Differential attractiveness of induced odors emitted by eight maize varieties for the parasitoid Cotesia marginiventris: is quality or quantity important? J Chem Ecol 28:951-968

Kant MR, Sabelis MW, Haring MA, Schuurink RC (2008) Intraspecific variation in a generalist herbivore accounts for induction and impact of host-plant defenses. Proc Roy Soc B 275:443-452

Kant MR, Bleeker PM, van Wijk M, Schuurink RC, Haring MA (2009) Plant volatiles in defence. Adv Bot Res 51:613-666

Krips OE, Willems PEL, Gols R, Posthumus MA, Gort G, Dicke M (2001) Comparison of cultivars of ornamental crop Gerbera jamesonii on production of spider mite-induced volatiles, and their attractiveness to the predator Phytoseiulus persimilis. J Chem Ecol 27:1355-1372

Loughrin JH, Manukian A, Heath RR, Tumlinson JH (1995) Volatiles emitted by different cotton varieties damaged by feeding beet armyworm larvae. J Chem Ecol 21:1217-1227 
Norton AP, English-Loeb GM, Belden E (2001) Host plant manipulation of natural enemies: leaf domatia protect beneficial mites from insect predators. Oecologia 126:535-542

Onzo A, Hanna R, Zannou I, Sabelis MW, Yaninek JS (2003) Dynamics of refuge use: diurnal, vertical migration by predatory and herbivorous mites within cassava plants. Oikos 101:59-69

Onzo A, Hanna R, Negloh K, Toko M, Sabelis MW (2005) Biological control of cassava green mite with exotic and indigenous phytoseiid predators-effects of intraguild predation and supplementary food. Biol. Control 33:143-152

Onzo A, Hanna R, Sabelis MW (2009) Within-plant migration of the predatory mite Typhlodromalus aripo from the apex to the leaves of cassava: response to day-night cycle, prey location and prey density. J Insect Behav 22:186-195

Onzo A, Sabelis MW, Hanna R (2010) Effects of ultraviolet radiation on predatory mites and the role of refuges in plant structures. Environ Entomol 39:695-701

Price PW, Bouton CE, Gross P, McPheron BA, Thompson JN, Weis AE (1980) Interactions among three trophic levels: influence of plants on interactions between insect herbivores and natural enemies. Annu Rev Entomol 11:41-45

Sabelis MW, Bakker FM (1992) How predatory mites cope with the web of their tetranychid prey: a functional view on dorsal chaetotaxy in the Phytoseiidae. Exp Appl Acarol 16:203-225

Sabelis MW, van de Baan HE (1983) Location of distant spider-mite colonies by phytoseiid predators: demonstration of specific kairomones emitted by Tetranychus urticae and Panonychus ulmi (Acari: Tetranychidae). Entomol Exp Appl 33:303-314

Sabelis MW, van Baalen M, Bakker FM, Bruin J, Drukker B, Egas M, Janssen ARM, Lesna IK, Pels B, van Rijn PCJ, Scutareanu P (1999) The evolution of direct and indirect plant defence against herbivorous arthropods. In: Olf H, Brown VK, Drent RH (eds) Herbivores: between plants and predators. Blackwell, Oxford, pp 109-166

Sabelis MW, Takabayashi J, Janssen A, Kant MR, van Wijk M, Sznajder B, Aratchige NS, Lesna I, Belliure B, Schuurink RC (2007) Ecology meets plant physiology: herbivore-induced plant responses and their indirect effects on arthropod communities. In: Ohgushi T, Craig TP, Price PW (eds) Ecological communities: plant mediation in indirect interaction webs. Cambridge University Press, Cambridge, pp 188-217

Scutareanu P, Bruin J, Drukker B, Posthumus MA, Sabelis MW (2001) Pear tree responses to psyllid infestation: intercultivar variation in emission of volatiles. Integr Fruit Prod IOBC/WPRS Bull 24:221-226

Scutareanu P, Bruin J, Posthumus MA, Drukker B (2003) Constitutive and herbivore-induced volatiles in pear, alder and hawthorn trees. Chemoecology 13:63-74

Shiojiri K, Ozawa R, Kugimiya S, Uefune M, van Wijk M, Sabelis MW, Takabayashi J (2010) Herbivorespecific, density-dependent induction of plant volatiles: honest or "cry wolf' signals? PLoS One 5(8):e12161. doi:10.1371/journal.pone.0012161

Skirvin DJ, Fenlon JS (2001) Plant species modifies the functional response of Phytoseiulus persimilis (Acari: Phytoseiidae) to Tetranychus urticae (Acari: Tetranychidae): implications for biological control. Bull Entomol Res 91:61-67

Sokal RR, Rohlf FJ (1981) Biometry, 2nd edn. Freeman and Company, New York

Takabayashi J, Dicke M (1992) Response of predatory mites with different rearing histories to volatiles of uninfested plants. Entomol Exp Appl 64:187-193

Takabayashi J, Dicke M, Posthumus MA (1991) Variation in composition of predator-attracting allelochemicals emitted by herbivore-infested plants: relative influence of plant and herbivore. Chemoecology 2:1-6

Takabayashi J, Dicke M, Posthumus MA (1994) Volatile herbivore-induced terpenoids in plant-mite interactions: variation caused by biotic and abiotic factors. J Chem Ecol 20:1329-1354

Tamiru A, Bruce TJA, Woodcock CM, Caulfield JC, Midega CAO, Ogol CKPO, Mayon P, Birkett MA, Pickett JA, Khan ZR (2011) Maize landraces recruit egg and larval parasitoids in response to egg deposition by a herbivore. Ecol Lett 14:1075-1083

Turlings TCJ, Tumlinson JH, Lewis WJ (1990) Exploitation of herbivore-induced plant odors by hostseeking parasitic wasps. Science 250:1251-1253

Turlings TCJ, Loughrin JH, Röse U, McCall PJ, Lewis WJ, Tumlinson JH (1995) How caterpillar-damaged plants protect themselves by attracting parasitic wasps. Proc Natl Acad Sci USA 92:4169-4174

van Wijk M, de Bruijn PJA, Sabelis MW (2011) Complex odor from plants under attack: herbivore's enemies react to the whole, not its parts. PLoSONE 6(7):e21742. doi:10.1371/journal.pone.0021742

Walter DE (1996) Living on leaves: mites, tomenta, and leaf domatia. Annu Rev Entomol 41:101-114

Zar J (1984) Biostatistical analysis, 2nd edn. Prentice-Hall Inc., London, p 620

Zundel C, Nagel P, Hanna R, Korner F, Scheideger U (2009) Environment and host-plant genotype effects on the seasonal dynamics of a predatory mite on cassava in sub-humid tropical Africa. Agric For Entomol 11:321-331 